\title{
Religious/Spiritual Struggles and Life Satisfaction among Young Roman Catholics: The Mediating Role of Gratitude
}

\author{
Małgorzata Szcześniak *D, Grażyna Bielecka, Iga Bajkowska, Anna Czaprowska and Daria Madej \\ Faculty of Humanities, Institute of Psychology, University of Szczecin, ul. Krakowska 69, 71-017 Szczecin, \\ Poland; grazynabielecka6@gmail.com (G.B.); iga.bajkowska@wp.pl (I.B.); czapranna1a@gmail.com (A.C.); \\ daria.madej77@gmail.com (D.M.) \\ * Correspondence: malgorzata.szczesniak@whus.pl
}

Received: 11 May 2019; Accepted: 19 June 2019; Published: 22 June 2019

\begin{abstract}
An extensive review of the psychological literature shows that interactions between religious/spiritual (R/S) struggles and other aspects of human functioning are complex and affected by "third" factors. Still, we have only a few studies that confirm R/S struggles as a source of well-being and indicate the ways in which it happens. In the present study, we aimed to verify whether the relationship between $R / S$ struggles and life satisfaction was mediated by dispositional gratitude that seems to offer protection in times of adversity and turmoil. The sample consisted of 440 Roman Catholics (331 women) from Poland aged between 18 and 40. We applied the Religious Comfort and Strain Scale, the Satisfaction with Life Scale, and the Gratitude Questionnaire. In line with our hypotheses, it was confirmed that respondents with higher life satisfaction were more likely to display a higher sense of trust in God. They also declared a lower fear/guilt and perception of God as abandoning people. Gratitude correlated positively and significantly with religious comfort, and negatively with emotions towards God and social interactions surrounding religion. Moreover, it can be affirmed that dispositional gratitude mediated the relationship between three of four dimensions of religious strain and life satisfaction: religious comfort, negative emotions towards God, and negative social interactions surrounding religion.
\end{abstract}

Keywords: religious/spiritual struggles; life satisfaction; gratitude; mediation

\section{Introduction}

Poland, with at least three-quarters of adults (87\%) identifying themselves as Catholics (Pew Research Center; PRC Pew Research Center), is one of the European countries where Catholics are still the largest religious group. However, different studies (Büssing et al. 2014) report that the situation in Poland has lately begun to change, and religion is gradually becoming a private matter for some believers, beyond institutionalized participation. In fact, the religious profile of Poland, presented by a recent PRC (Pew Research Center) report and based on an overall combined index, shows that $23 \%$ of Polish young adults under 40 are significantly less likely to consider religion as very important in their lives, compared with $40 \%$ of older ones. Similar patterns are found in 45 other states out of 106 countries surveyed by PRC (Pew Research Center). Although the reasons for the age gap in religious commitment are complex and mostly related to different historical and socio-cultural factors, it is plausible to assume that such disparity may reflect struggles faced by the young generation on different levels of religious and spiritual life (Kwako Golo et al. 2019). A significant body of literature (Sedlar et al. 2018) has revealed that religious/spiritual (R/S) struggles are not uncommon and are strongly interconnected with greater health problems (McConnell et al. 2006). People can struggle 
with their faith in response to trauma or stressful events (Currier et al. 2018), a serious, life-threatening experience such as heart failure (Magyar-Russell et al. 2014; Park et al. 2011), different forms of cancer (Fitchett et al. 2004; Sherman et al. 2005), bereavement (Burke and Neimeyer 2014; Cowchock et al. 2010; Neimeyer and Burke 2011), indicators of emotional distress (Exline and Rose 2005) such as anxiety (Zarzycka and Zietek 2018) and depression (Exline et al. 2000; Murphy et al. 2016), and a lower well-being or satisfaction with life (Wilt et al. 2016; Zarzycka and Zietek 2018). R/S struggles might be related to extrinsic, intrinsic, and quest religiousness (Hill and Pargament 2008), as well. For example, in a few studies (Johnson et al. 2008), quest, which expresses religious doubt, was positively related to religious struggle, hence questioning one's religious beliefs can be perceived as one type of spiritual crisis (Fisher 2017). An interesting pattern of results was also obtained by researchers exploring distinct motivations for life satisfaction and being religious (Felere and Lavrič 2008). It was found that while well-being positively correlated with intrinsic religiosity, it correlated negatively with extrinsic religiosity and religious quest (Dowson and Miner 2015; García-Alandete and Valero 2013).

Nevertheless, little research exists on the character of the relationship between R/S struggles and life satisfaction (Zarzycka and Puchalska-Wasyl 2019). Specifically, it still remains unclear through which mediating or moderating mechanism both variables are associated. In fact, Hill (2005) observes that comprehending the varieties of "how" an individual's R/S life is experienced remains of utmost importance, especially when psychologists try to understand the process that links religion to some other phenomena. We chose a group of young adults, building upon the conclusions of some researchers (Galek et al. 2007; Krause et al. 1999) who found that the noxious effects of religious doubt were less strongly felt in older than in younger adults. According to some other outcomes (Krause 2015) obtained across different samples, as age increases, religious doubt diminishes.

\subsection{Religious and Spiritual Struggles}

R/S struggles denote hypothetically challenging facets of R/S life (Sedlar et al. 2018) and "occur when some aspects of R/S belief, practice, or experience become a focus of negative thoughts or emotions, concern, or conflicts" (Exline et al. 2014b, p. 208). This phenomenon is also defined as the experience of pressure or confusion about the sacred, spiritual, or religious apprehensions that influence relationships with the Divine, others, and the self (Gutierrez et al. 2017; Pargament et al. 2005).

In the divine domain, some people perceive God more as controlling and just than caring, loving, merciful, and comforting (Edmondson et al. 2008). For these individuals, God is distant, revengeful, and punitive (Ellison and Lee 2010) and they tend to harbor feelings of disappointment, abandonment by God, and anger at a higher power (Ano and Pargament 2013; Ellison and Lee 2010; King et al. 2017). In some cases, troubled relationships with God lead to questioning His existence (Ellison and Lee 2010). Interpersonal R/S struggles implicate religious conflicts between an individual and religious institutions, community members, clergy, followers of other confessions, and/or unbelievers (Exline et al. 2014a; Sedlar et al. 2018; Zarzycka and Zietek 2018). According to Ellison and Lee (2010), not all religious groups are perceived as supportive networks. Indeed, negative interpersonal religious experience may stem from disagreements over ordinary problems linked to jealousy, selfishness, or hypocrisy within the community, and more considerable issues related to theology, politics, morality, or economics. In the intrapersonal or intrapsychic domain (Ellison and Lee 2010), R/S struggles may take the form of both long-lasting religious doubting (Ellison et al. 2010) and impressions of unworthiness, fear, and guilt (Ano and Pargament 2013; King et al. 2017). Such persistent and unresolved doubts can threaten important characteristics of personal identity, are severely confusing, and are inversely associated with different indicators of well-being (Ellison et al. 2010). Distressing worries can emerge from challenges presented by scientific advances, doubts concerning religious doctrines, injustice, loss of meaning in life, one's own lack of coherence, and transgressions (Ellison and Lee 2010; Zarzycka and Puchalska-Wasyl 2019; Zarzycka and Zietek 2018).

Investigations point to a normative character of R/S struggles that constitute an important and expected part of human life (Exline et al. 2014a, 2014b; Exline and Rose 2005; Magyar-Russell et al. 
2014; Sedlar et al. 2018; Tobin and Slatcher 2016). In fact, some theologians maintain that religious doubts are inevitable and may play a beneficial role in personal spiritual growth (Ellison et al. 2013). Likewise, Pargament et al. (2005, p. 246) emphasize that in both Jewish and Christian traditions, $\mathrm{R} / \mathrm{S}$ struggles denote essential "forks in the road" that, depending on how they are coped with, can lead to development and renewal or hopelessness and desperation. Resolved, adaptive, or positive R/S struggles usually reflect a secure bond with God, constructive relatedness with others, and lifelong confidence, based on the conviction of being loved by the Divinity. In contrast, unresolved, maladaptive, or negative R/S strains involve a more vulnerable kind of relationship with God, a feeling of spiritual alienation from other believers, and reduced meaning of personal life.

While a significant body of evidence reveals that a positive pattern of religious coping results in mental health (Ellison et al. 2013) and higher life satisfaction through the capacity to make meaning of religious doubt (Zarzycka and Zietek 2018), a negative pattern shows reverse associations with quality of life in its different dimensions and adverse mental health effects among various samples (Ellison et al. 2013).

\subsection{Life Satisfaction and R/S Struggles}

Interest in life satisfaction, understood as a conscious judgment of one's quality of life on the basis of one's own unique set of principles (Pavot and Diener 1993), has a long history in the field of psychology (Lim and Putnam 2010). Various academic researchers distinguish a wide range of factors that affect a subjective assessment of human well-being (Lim and Putnam 2010) and consider religion to be one of them. In fact, religion seems to have beneficial effects on physical and mental health (George et al. 2002; Koenig et al. 2001; Zarzycka and Puchalska-Wasyl 2019; Zarzycka and Zietek 2018). Although a positive relationship between religiosity and life satisfaction is well-established (Krok 2014; ten Kate et al. 2017), less is known about R/S struggles and their potential influence on people's quality of life. The majority of studies report that religious struggles worsen health (Ano and Vasconcelles 2005; Smith et al. 2003), weaken personal adjustment and harm well-being (Ano and Vasconcelles 2005), make recovery and rehabilitation more difficult (Fitchett et al. 1999), and predict higher mortality rates (Pargament et al. 2001). In a cross-sectional survey, Büssing and colleagues (Büssing et al. 2013) found that a lack of positive spiritual feelings ("spiritual dryness") among 3.824 Catholic priests correlated moderately negatively with life satisfaction. Correspondingly, results derived from an ongoing nationwide survey in the United States among participants at least 66 years old (Krause 2015) showed that greater religious doubt was associated with less life satisfaction. In the Alcoholics Anonymous group, Zarzycka et al. (2017) observed that religious comfort correlated positively with the general assessment of quality of life $(r=0.52, p<0.001)$ and life satisfaction $(r=0.41, p<0.001)$. Fear/guilt and negative emotions towards God correlated negatively with quality of life $(r=-0.29$, $p<0.01 ; r=-0.36, p<0.001)$. Negative social interactions surrounding religion did not correlate with the assessment of quality of life. In a nationally representative sample of American adults $(N=2.208)$, the magnitudes of the correlations between the R/S struggle subscales (divine, demonic, interpersonal, intrapersonal, and ultimate-meaning) and life satisfaction were slightly higher than with happiness (between -0.14 and -0.32 vs. -0.08 and -0.30 , respectively) (Abu-Raiya et al. 2015). In similar studies (Zarzycka and Puchalska-Wasyl 2019), only divine, demonic, and ultimate-meaning struggle correlated negatively with well-being. In most cases, the relations between different types of religious conflicts mentioned in the majority of the foregoing studies were rather weak.

However, negative forms of religious coping can also relate to positive psychological adjustment (Ano and Vasconcelles 2005) and act as potential "turning points" (Exline and Rose 2005, p. 312). For example, some researchers claim (Desai and Pargament 2015) that people can benefit from their struggles in the religious or spiritual sphere. Other psychologists (Exline and Rose 2005) remark that R/S struggles may, paradoxically, contribute to enriching individuals' lives. Pargament and colleagues (Pargament et al. 2005) observe that religious crises are perceived in many religious traditions as opportunities for spiritual growth. Likewise, this view finds its confirmation in the philosophical 
wisdom (Proffitt et al. 2007) and psychological theories (e.g., Erikson and his development through well-solved crises; Tedeschi and Calhoun and their concept of post-traumatic growth, to mention only a few) that consider struggles and major crises an occasion for growth experience.

\subsection{R/S Struggles, Life Satisfaction, and Gratitude}

An extensive review of the psychological literature shows that interactions between R/S struggles and other aspects of human functioning are quite complex and often affected by "third" factors (Pargament et al. 2005). Still, we have only a few studies that confirm R/S struggles as a source of well-being and indicate the ways in which they happen (Zarzycka and Zietek 2018). For example, the relationship between R/S struggles and well-being is found to be mediated or moderated by internal dialogical activity (Zarzycka and Puchalska-Wasyl 2019), the support received in times of crisis (Holcomb and Nonneman 2004), age, living status-alone or in a marriage, illness or soundness, and identification with a particular religious community or spiritual tradition (Zarzycka and Zietek 2018). The mediatory or moderator role of the above-mentioned variables may lead to an increase or decrease in well-being during R/S struggles (Zarzycka and Puchalska-Wasyl 2019).

In the present study, we chose dispositional gratitude as a potential mediator between $R / S$ struggles and life satisfaction. Although the word "gratitude" has a number of various connotations, depending on the context in which it occurs (Sansone and Sansone 2010), for our purpose, we assumed the definition according to which dispositional gratitude refers to a life orientation towards perceiving and appreciating the positive (Wood et al. 2008a, 2008b). This conceptualization is in line with Bertocci and Millard (1963, p. 389) definition, according to which gratitude is "the willingness to recognize the unearned increments of value in one's experience". At its core lies the deep conviction that appreciation arises in the framework of meaning. In other words, being thankful relates to relevant events that do not necessarily have immediately positive character to which people are typically accustomed. Likewise, Emmons (2013) highlights that a grateful attitude to life seems to offer protection in times of turmoil and builds a more extensive resiliency in the face of adversity and crisis. Moreover, it has the power to heal, energize, and transform hardship into opportunity. Some convincing evidence of the positive influence of gratitude in different difficult circumstances comes from several empirical studies. For example, Fredrickson and colleagues (Fredrickson et al. 2003) confirmed that even in the context of the 11 September attacks, gratitude was one of the three most frequently experienced emotions. The tragedy of this event made many people more aware and thankful for their own safety and the safety of their families. Therefore, gratitude seems to be a powerful resilience factor that may help individuals to deal with various forms of crises. A recent report by Wong and colleagues (Wong et al. 2017) confirmed that participants in the Gratitude Group Program showed a significant and clinically meaningful decrease in psychological distress. Hence, gratitude helps people to take up a perspective by which they can view life in its wholeness and are not overwhelmed by difficult conditions. Still, in another study, researchers (Poelker et al. 2017) observed that gratitude played an important role in the lives of Guatemalan adolescents who were economically disadvantaged. In fact, the grateful-feeling youth had a higher desire to repay the kindness shown to them, and experienced greater satisfaction with life. These data confirm that besides its connection with R/S struggles, gratitude positively relates to life satisfaction (Büssing et al. 2018; Fagley 2012; Froh et al. 2009a, 2009b). Well-documented research shows that grateful people are more prompt to perceive positive experiences in their daily life (Büssing et al. 2018) and consider negative events as less influential on the present (Lambert et al. 2009). The latter competence helps to reframe adverse and harmful memories from the past and assists in mood repair resulting from a stressful event (Watkins 2004).

\subsection{Research Problem and Hypotheses}

In this study, we aimed to verify whether the relationship between R/S struggles and life satisfaction was mediated by dispositional gratitude. Whereas there is enough evidence that $R / S$ struggles may exacerbate quality of life (Exline and Rose 2005), the ways in which R/S strains can increase psychological 
resources and lead to constructive outcomes are still understudied and less established (Zarzycka and Zietek 2018). Therefore, based on the literature review, we hypothesized that:

Hypothesis 1 (H1). Religious comfort is positively related to life satisfaction, and other dimensions of religious struggle (fear/guilt, negative emotions towards God, negative social interactions related to religion) correlate negatively with life satisfaction.

Hypothesis 2 (H2). Religious comfort is positively related to a grateful disposition, and other dimensions of religious struggle (fear/guilt, negative emotions towards God, negative social interactions related to religion) correlate negatively with a grateful disposition.

Hypothesis 3 (H3). A grateful disposition mediates the effect of four dimensions of religious struggle on life satisfaction.

Hypothesis $\mathrm{H} 3$ can induce some questions, as the appropriateness of a cross-sectional design for studying mediation is still being discussed (Aguinis et al. 2017; Maxwell and Cole 2007). Nevertheless, Kline (2015) and Fairchild and McDaniel (2017) recognize that an indirect effect can be established when there is a substantial rationale for temporal ordering specifications of the examined variables. In this respect, the literature pertinent to the assessment of the relationship between religion and satisfaction mostly shows that religiosity affects life satisfaction (Yeniaras and Akarsu 2017). Silberman (2005, p. 645) describes religiousness as "a lens through which reality is perceived and interpreted". This is in accordance with theories that treat religion as an antecedent which has its psychological effects on cognitions, emotions, and behaviors (Heelas 1985). Although there are no studies on R/S struggles and life satisfaction with a grateful disposition as the intervening variable, there is some empirical research on the psychological antecedents of satisfaction and well-being that provides an initial base that such an indirect effect can be confirmed.

\section{Materials and Methods}

\subsection{Ethics Approval}

The study and the protocol were approved by the Bioethics Committee of the Institute of Psychology at the University of Szczecin and conducted according to the Declaration of Helsinki.

\subsection{Participants}

The sample consisted of 440 Roman Catholics (331 women) aged between 18 and 40. The average age was approx. $23(M=23.29 ; S D=5.06)$. In terms of subjective evaluations of their own levels of religiosity, $8 \%$ of participants declared a lack of religious involvement, 33\%-low, $25 \%$-medium, $26 \%$-rather high, and $8 \%$-very high.

\subsection{Data Collection}

The participants were recruited through selected online Internet communities and groups for Roman Catholics. All of the respondents who agreed to take part in the survey were presented with general information about the research goals and were prompted with a web-based informed consent. Only after providing their agreement, the participants were invited to fill in the questionnaires. Respondents under the age of 18 and above 40 were excluded from participation as a target sample group was selected to meet the "young adults" criterion.

\subsection{Assessment of the Religious Comfort and Strain Scale (RCSS)}

RCSS, designed by Exline and colleagues (Exline et al. 2000) and adapted into Polish by Zarzycka (2014), is a questionnaire of 28 items that measures religiosity as a source of comfort 
(one subscale) and struggle (three subscales). Participants rate each item on an 11-point Likert scale (from $0=$ not at all to $10=$ extremely) (Zarzycka 2014). Religious comfort estimates the sense of trust in God, and feeling God as omnipotent and caring. It assesses perceiving faith as a source of strength, meaning, and purpose in life (Zarzycka et al. 2017). The subscale of fear and guilt concerns a preoccupation with one's own misdeeds and feelings of being unforgiven by God. The subscale of negative emotions toward God refers to negative feelings toward God, perceiving God as abandoning people, unjust, punishing, and untrustworthy. The subscale of negative social interactions surrounding religion evaluates the intensity of adverse emotions and relations with fellow congregants and believers. In the current study, the $\alpha$ of religious comfort was 0.98 , of fear/guilt was 0.80 , of negative emotions toward God was 0.84 , and negative interactions surrounding religion was 0.78 .

\subsection{Assessment of the Satisfaction with Life Scale (SWLS)}

SWLS, originated by Diener et al. (1985) and adapted into Polish by Juczyński (2001), is a short five-item scale that measures one's life satisfaction as a whole, not in specific aspects. The respondents evaluate each of five statements by using multiple-choice answers on a 7-point Likert scale that ranges from $1=$ strongly disagree to $7=$ strongly agree. The possible range of scores is between 5 and 35 . The higher the final score, the more intense is the general satisfaction with life. Different studies report a good coefficient alpha of 0.82 (Diener et al. 1985). In the present study, Cronbach's alpha was 0.85.

\subsection{Assessment of the Gratitude Questionnaire (GQ-6)}

GQ-6, developed by McCullough et al. (2002) and adapted into Polish by Kossakowska and Kwiatek (2014), is a six-item self-report instrument assessing gratitude as a dispositional trait (example item: "I am grateful to a wide variety of people"). Respondents endorse each item on a 7-point Likert-type scale, ranging from $1=$ strongly disagree to $7=$ strongly agree. Two items are negatively worded and require reverse coding $\left(n^{\circ} 3\right.$ and $\left.n^{\circ} 6\right)$. The higher the sum of points, the greater the intensity of dispositional gratitude. The reliability coefficients Cronbach's $\alpha$ of the original English version of the questionnaire was 0.82 . In the adapted version, $\alpha$ was 0.71 , and in the present study, $\alpha$ was 0.67 . Such reliability recurs in many studies (Kossakowska and Kwiatek 2014).

\subsection{Statistical Analysis}

Data analyses were performed using the Statistical Package for the Social Sciences (SPSS software version 20, IBM, Armonk, NY, USA) with significance accepted if $p<0.05$. Missing data was averted as the statements of each online questionnaire needed to be $100 \%$ complete before continuing to the next section of scales. The data distribution was checked using the statistics of skewness and kurtosis to determine how much the variables deviated from the normal curve (Morgan and Griego 1998). Descriptive statistics were calculated and Pearson's correlation coefficients @for parametric data were assessed to explore the association between variables including religious struggle, life satisfaction, and dispositional gratitude.

The statistical power for the current study was conducted using G*Power 3.1.9.4 (Faul et al. 2007) to determine the appropriate sample size (Anderson et al. 2017). We applied the recommended higher power criteria of 0.95 (Anderson et al. 2017; Lakens 2013) and a significance criterion $\alpha$ of 0.05 to detect a small and realistic effect $\left(\mathrm{f}^{2}=0.025\right.$ is considered a benchmark threshold for a small effect). The reason for using the value of $\mathrm{f}^{2}$ was because there was no previous research on the relationship between religious struggle and life satisfaction among nonclinical groups of participants. In a case of novel studies, Cohen (1988) suggests such a choice. Moreover, different scholars (Aguinis et al. 2005; Martell et al. 1996) claim that as long as a small effect has a significant impact for science or practice, it should be considered in research designs. The $G^{*}$ Power analysis showed that a power of 0.95 would require a minimum sample size of 435 respondents.

Furthermore, we used a linear regression model to control for various possible confounding variables and to verify if they were not a threat to the validity of mediation analyses. First, considering 
that four dimensions of religious comfort and strain were associated with each other and used as predictors while accounting for covariates, we examined whether there would be a high redundancy among predictors and multicollinearity problem by using an index of tolerance statistics and variance inflation factors (VIFs). Second, we checked the data for outliers, using Mahalanobis' distance and Cook's distance. Third, the participants' sex and age were included to control for their potential influence on the relationship between the independent variable of interest (religiosity struggle) and with the outcome variable (life satisfaction). In fact, both theoretical and empirical examinations of the impact of religious struggle in relation to demographic variables found differences between women and men, and younger and older participants (Cokley et al. 2013). The potential confounders were entered at Step 1. All variables hypothesized as predictors of life satisfaction were entered at Step 2.

The PROCESS macro (version 3.2) (Hayes 2013) was run to examine whether dispositional gratitude mediated the association between the four dimensions of religious struggle separately and life satisfaction. Figure 1 illustrates the pattern of relationships that characterize the mediation dynamic. Religious comfort, fear/guilt, negative emotions towards God, and negative social interactions surrounding religion were the independent variables, and life satisfaction was the dependent variable. Dispositional gratitude acted as a mediating variable. Thus, there were four single-level mediation models (according to Hayes, we applied Model no. 4), involving three-variable systems. For the current analysis, bootstrapping procedures were performed. As recommended by Preacher and Hayes (2008), 5000 bootstrap samples and 95\% confidence intervals were used to estimate the indirect effects that are considered significant if they do not include zero. This method is considered to be more powerful than traditional mediation analyses as it does not assume the normality of the sampling distribution (Hayes 2013).

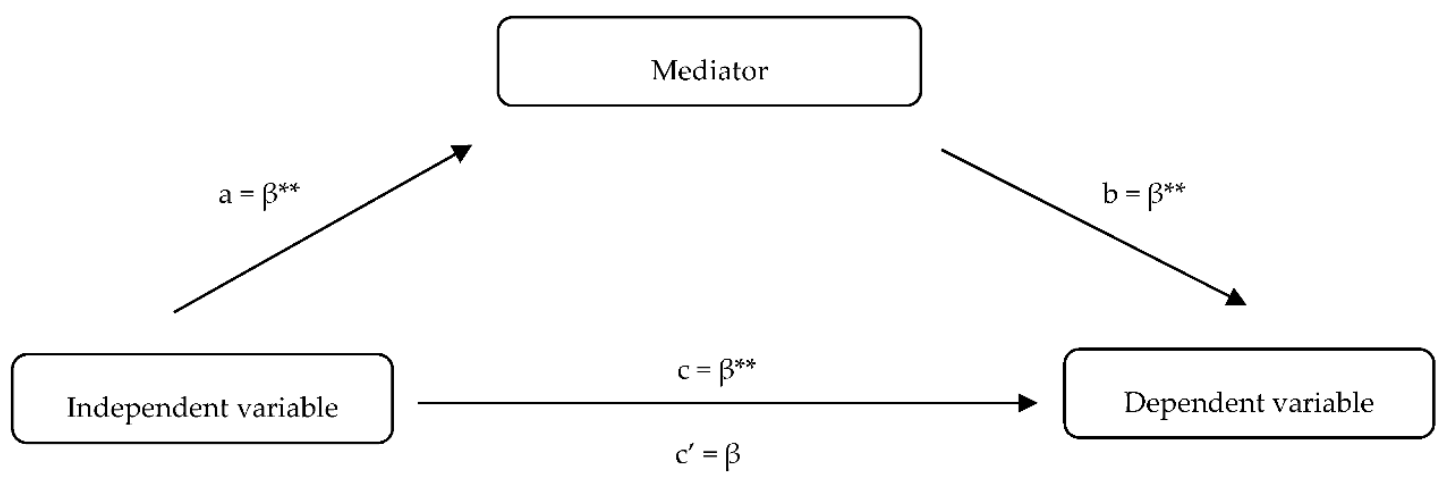

Figure 1. Theoretical model of the role of the mediator in the relationship between religious struggle and life satisfaction. ${ }^{*} p<0.05 ;{ }^{* *} p<0.01$.

\section{Results}

\subsection{Preliminary Analyses}

Religious comfort, fear and guilt, negative emotions towards God, negative social interactions surrounding religion, satisfaction with life, and gratitude disposition were screened for skewness and kurtosis to evaluate the normality of the scale's distribution. We assumed values less than \pm 2 commonly considered acceptable as a normal distribution (George and Mallery 2016). In fact, no variables exceeded the cutoffs of \pm 2 (Table 1 ). 
Table 1. Descriptive statistics for the Religious Comfort and Strain Scale (RCSS), the Satisfaction with Life Scale (SWLS), and the Gratitude Questionnaire (GQ-6), $(N=440)$.

\begin{tabular}{lccccccc}
\hline \multicolumn{1}{c}{ Scales } & Min & Max & M & SD & Skewness & Kurtosis & $\alpha$ \\
\hline 1. RC & 1.00 & 10.00 & 4.995 & 2.967 & 0.236 & -1.285 & 0.98 \\
2. FG & 1.00 & 6.00 & 3.137 & 1.741 & 0.815 & 0.289 & 0.80 \\
3. NEG & 1.00 & 5.00 & 2.613 & 1.794 & 1.347 & 1.302 & 0.84 \\
4. NSIR & 1.00 & 7.00 & 4.483 & 1.846 & 0.409 & -0.290 & 0.78 \\
5. SWL & 1.00 & 5.00 & 4.126 & 1.214 & -0.206 & -0.296 & 0.85 \\
6. GD & 1.00 & 6.00 & 5.022 & 0.949 & -0.656 & 0.552 & 0.67 \\
\hline
\end{tabular}

Religious comfort (RC); Fear and guilt (FG); Negative emotions toward God (NEG); Negative social interactions (NSIR); Satisfaction with life (SWL); Gratitude disposition (GD).

\subsection{Correlation Analysis}

In line with our hypotheses (H1 and H2), life satisfaction negatively correlated with fear/guilt and "negative" emotions towards God, and positively with religious comfort (Table 2). These relationships were found to be statistically significant at $p$-values $<0.01$. In other words, it was confirmed that respondents with higher life satisfaction were more likely to display a higher sense of trust in God, a lower fear/guilt, and perception of God as abandoning people. At the same time, gratitude correlated positively and significantly with religious comfort, and negatively with emotions towards God and social interactions surrounding religion.

Table 2. Correlation matrix between dimensions of religious struggle (RCSS), life satisfaction (SWLS), and gratitude (GQ-6) $(N=440)$.

\begin{tabular}{lcccccc}
\hline & $\mathbf{1}$ & $\mathbf{2}$ & $\mathbf{3}$ & $\mathbf{4}$ & $\mathbf{5}$ & $\mathbf{6}$ \\
\hline 1. RC & 1 & & & & & \\
2. FG & $0.377^{* *}$ & 1 & & & & \\
3. NEG & $-0.332^{* *}$ & $0.203^{* *}$ & 1 & & & \\
4. NSIR & $-0.240^{* *}$ & $0.125^{* *}$ & $0.304^{* *}$ & 1 & & \\
5. SWL & $0.299^{* *}$ & $-0.107^{*, \mathrm{t}}$ & $-0.292^{* *}$ & $-0.068^{\mathrm{t}}$ & 1 & \\
6. GRAT & $0.446^{* *}$ & $-0.083^{\mathrm{t}}$ & $-0.319^{* *}$ & $-0.186^{* *}$ & $0.478^{* *}$ & 1 \\
\hline
\end{tabular}

* $-p<0.05 ;{ }^{* *}-p<0.01$; ${ }^{\mathrm{t}}$-tendency; Religious comfort (RC); Fear/guilt (FG); Negative emotions toward God (NEG); Negative social interactions surrounding religion (NSIR); Satisfaction with life (SWL); Gratitude (GRAT).

\subsection{Multicollinearity and Confounding Variables}

Although no consensus occurs regarding which VIF cutoff score is most appropriate for collinearity (Thompson et al. 2017), we assumed a VIF index higher than 5.0 (Hair et al. 2017) and a tolerance value of less than 0.2 as indicative of multicollinearity (Mehmetoglu and Jakobsen 2017). Given that the analysis of multiple regression yielded a VIF of 1.02-1.76 and a tolerance rate ranging from 0.59 to 0.98 , multicollinearity indexes suggested little evidence of multicollinearity for these data. Mahalanobis' distance procedure was employed, using the chi-square distribution with a very conservative probability estimate for a case being an outlier $(p<0.001)$ (Fidell and Tabachnick 2003). Only three cases of 440 were identified as probable multivariate outliers. However, because a trial analysis run with and without the cases identified as outliers showed that they did not have a large effect on the regression and did not change results (Stevens 2009), we decided not to drop them from the analysis. Moreover, Cook's value (between 0.000 and 0.056) was well under the point at which the researcher should be concerned, that is, less than 1 (Fidell and Tabachnick 2003), suggesting that the cases are not problematic in terms of excessive influence on the model (Lomax and Hahs-Vaughn 2012). Hierarchical regression analyses indicated that neither sex nor age made a significant unique contribution to the model, explaining only $0.6 \%$ of variance $\left(R^{2}=0.006\right)$ : $\operatorname{sex}(\beta=0.003, \mathrm{t}=0.085$, $p=0.933)$ and age $(\beta=-0.048, \mathrm{t}=-1.179, p=0.239)$. Predictors explained additional $29 \%$ of the variance even after controlling for the effects of potentially confounding variables (sex and age). 


\subsection{Mediational Analyses}

For the purpose of further investigation of the relationship between the assessment of dimensions of religious struggle and life satisfaction, dispositional gratitude was introduced as a potential mediator which could weaken, strengthen, or have no influence on the existing correlation between the independent variables (religious comfort, fear/guilt, negative emotions toward God, and negative social interactions surrounding religion) and the dependent variable (life satisfaction) (Figure 1). Table 3 shows the statistics related to each mediation path.

Table 3. The role of dispositional gratitude (GQ-6) in the relationship between religious struggle (religious comfort, fear/guilt, negative emotions toward God, negative social interactions surrounding religion; RCSS) and life satisfaction (SWLS).

\begin{tabular}{lccccc}
\hline & $\mathbf{a}$ & $\mathbf{b}$ & $\mathbf{c}$ & $\mathbf{c}^{\prime}$ & $\mathbf{a b}$ \\
\hline 1. RC - DG - LS & $0.14^{* *}$ & $0.55^{* *}$ & $0.12^{* *}$ & 0.04 & 0.08 \\
2. FG - DG - LS & $0.04^{* *}$ & $0.64^{* *}$ & $-0.07^{*}$ & -0.10 & 0.3 \\
3. NEG - DG - LS & $-0.17^{* *}$ & $0.20^{* *}$ & $-0.20^{* *}$ & -0.11 & -0.09 \\
4. NSIR - DG - LS & $-0.10^{* *}$ & $0.62^{* *}$ & 0.04 & 0.01 & 0.03 \\
\hline
\end{tabular}

$* p<0.05 ; * * p<0.01 ; 1$. RC - DG - LS: Religious comfort - Dispositional gratitude - Life satisfaction; FG - DG - LS: Fear/guilt - Dispositional gratitude - Life satisfaction; NEG - DG - LS: Negative emotions towards God Dispositional gratitude - Life satisfaction; NSIR - DG - LS: Negative social interactions surrounding religion Dispositional gratitude - Life satisfaction; $a=$ effect of the predictor on the mediator; $b=$ effect of the mediator on the outcome; $c$ = effect of the predictor on the outcome; $c^{\prime}=$ direct effect of predictor on the outcome while controlling for the mediator; $\mathrm{ab}=$ indirect effect of the predictor on the outcome through the mediator.

The results obtained through bootstrap sampling (5000) with a 95\% confidence interval showed a significant role of dispositional gratitude as a mediator in three of four relationships between: (1) religious comfort and life satisfaction, B (SE) $=0.07$ (0.0119), 95\% CI [0.0560, 0.1022]; (2) negative emotions towards God and life satisfaction, B (SE) $=-0.09(0.0185), 95 \%$ CI $[-0.1316,-0.0581]$; and, (3) negative social interactions surrounding religion and life satisfaction, $\mathrm{B}(\mathrm{SE})=-0.04(0.0154)$, $95 \%$ CI $[-0.0908,-0.0306]$. In the case of FG - DG - LS, B (SE) $=-0.03(0.0165), 95 \%$ CI [-0.0034, 0.0609], there was no mediation as the indirect effect contained a zero, which indicates that it is statistically insignificant.

According to the obtained results, it can be affirmed that dispositional gratitude mediated the relationship between three of four dimensions of religious struggle and life satisfaction: religious comfort, negative emotions towards God, and negative social interactions surrounding religion. In all three cases, the original path $c$ dropped to $c^{\prime}$ as a result of including the mediator.

\section{Discussion}

The first purpose of this study was to examine the relationship between four dimensions of $\mathrm{R} / \mathrm{S}$ struggles, life satisfaction, and gratitude. The second aim was to verify whether dispositional gratitude mediated the relationships between R/S and satisfaction. To the best of our knowledge, the current study is the first to assess directly the topic of religious struggles, subjective life satisfaction, and gratitude. This research gives enough clear findings for all three hypotheses.

Firstly, the positive correlation between religious comfort and life satisfaction is consistent with the previous literature. For example, Koenig (2012) in his systematic review finds significant positive associations between R/S and well-being in a large majority of results. Krause and Hayward (2013) reveal that people who have greater confidence in God and endorse trust-based prayer beliefs are more likely to declare that they are satisfied in their lives. Moreover, religious comfort is positively correlated with satisfaction considered as a component of life quality. Those individuals who perceive faith as a source of strength and rely on God's help report greater well-being (Büssing and Mundle 2009; Zarzycka et al. 2017). Conversely, preserving negative feelings of guilt/fear towards God and community decreases life satisfaction. These outcomes are confirmed by other studies. The data suggest 
(Krause and Ellison 2003) that gaining forgiveness from God, and so having lower feelings of fear, alleviates self-reproach and leads to improvement of subjective well-being. Likewise, experiential representations of God or "heart knowledge" (Zahl and Gibson 2012) predict satisfaction with life. Related findings (Büssing et al. 2013) show that the perception of being distant from God negatively correlates with life satisfaction and dispositional optimism. It is understandable if we think that spiritual dryness is a marker of crisis (Büssing et al. 2016) and as such can be considered a threat to a global assessment of own-life quality. In another study, Büssing and colleagues (Büssing et al. 2017) report that engagement in the religious practices of doing good and helping those in need is moderately related to life satisfaction and weakly to well-being.

Secondly, a similar pattern of results can be observed between R/S struggles and gratitude. In this respect, Büssing and colleagues (Büssing et al. 2015) show that reliance on God's help correlates strongly with gratitude and awe. Other studies (Aghababaei et al. 2018) illustrate that religion may facilitate gratitude. In fact, participants who have higher scores on religiosity measures tend to display higher grateful disposition. More precisely, engagement in religious practice and perceiving God as the ultimate source of the benefits (intrinsic religiosity) expresses itself in gratitude. On the other hand, using religion for personal benefits and conformity (extrinsic religiosity) negatively associates with gratitude (Watkins et al. 2003).

Finally, gratitude plays a mediating role in the relationships between three dimensions of R/S struggles (religious comfort, negative emotions towards God, negative social interactions surrounding religion) and life satisfaction. It seems that a grateful disposition, which manifests itself in a readiness to recognize the unearned increments of value in one's experience, is not indifferent to life satisfaction in the context of religious struggles both in their positive and negative dimensions. This outcome is in line with the concept of the broaden-and-build theory. According to this theory (Fredrickson 2001), positive emotions generate broad thought-action repertories that develop enduring personal physical, intellectual, psychological, and social resources. In fact, some researchers (Park et al. 2009) demonstrate that $R / S$ struggles have effects on health behaviors that are mediated by a positive effect of self-assurance. Other findings (Wood et al. 2008a, 2008b) provide further evidence that gratitude leads to lower levels of stress, which undoubtedly goes along with religious strains. In conclusion, compared with less grateful people, more grateful individuals might report experiencing higher life satisfaction in spite of undergoing negative thoughts or emotions with respect to their faith. It could be related to their ability to perceive and appreciate other aspects of life not involved directly in their beliefs and their relationship with God. Other studies (Kleiman et al. 2013) demonstrate that a higher level of gratitude and appreciation is a protective factor against harmful symptoms.

\section{Limitations}

Although promising, this research is not exempt from a number of limitations. Given that the participants were recruited mainly through a university website, it cannot be expected that they reflect the general Catholic population. Moreover, the limited information provided, restricted to age, sex, and subjective evaluation of their own level of religiosity, narrows down the possibility of a deeper interpretation of the outcomes. In the light of some studies reported in the introductory part that showed an important role of health assessment in the R/S struggles, it seems that this possible 'disturbing' factor should be taken into consideration. Consequently, in future studies, it would be meaningful to broaden the research samples and include a wider range of relevant potential confounding variables that might have an effect on the results, such as: causes of religious strains, intensity of struggles, engagement in religious practices, subjective assessment of health, distress, and bereavement, economic and marital status, and levels of education. An important limitation concerns the age of the participants, restricted to young Catholics, which makes the study unrepresentative. It would be enriching to extend the sample to middle and late adults to verify the possible similarities and differences between groups in experiencing R/S struggles in the context of life satisfaction and dispositional gratitude. It seems compelling, especially when we see that the available literature on the age differences in the relationship 
between religious doubt and well-being is ambiguous (Krause et al. 1999). In fact, Fisher (2017) suggests that more research needs to be done in the areas of religious change and faith crises. Furthermore, although we found evidence for the mediating role of grateful disposition on the relationship between $\mathrm{R} / \mathrm{S}$ struggles and life satisfaction, we were unable to assess causality in these associations because of the cross-sectional design assumed in the present study. However, we examined mediation in cross-sectional data offering an appropriate rationale for the posited mediation process. In the future, it would be meaningful to use a longitudinal design to better understand how R/S struggles might impact life satisfaction through the hypothesized mediating gratitude.

\section{Conclusions}

The study increases our knowledge about R/S struggles and gratitude among young Polish Catholics and confirms previous research about the relationship between $R / S$ strains and life satisfaction. Although the correlational and mediatory character of our findings does not allow us to draw causal conclusions, the results imply that the co-occurrence of gratitude in the context of $\mathrm{R} / \mathrm{S}$ struggles may be meaningful for life satisfaction, strengthening the association between religious comfort and subjective life satisfaction, and alleviating the link between negative emotions towards God/negative social interactions surrounding religion and life satisfaction.

Author Contributions: Conceptualization, M.S.; Data curation, M.S., G.B., I.B. and D.M.; Investigation, G.B., I.B., A.C. and D.M.; Methodology, M.S.; Project administration, I.B. and A.C.; Resources, M.S., G.B., I.B., A.C. and D.M.; Supervision, M.S.; Writing—original draft, M.S. and G.B.

Funding: This research received no external funding.

Conflicts of Interest: The authors declare no conflict of interest.

\section{References}

Abu-Raiya, Hisham, Kenneth I. Pargament, Neal Krause, and Gail Ironson. 2015. Robust links between religious/spiritual struggles, psychological distress, and well-being in a national sample of American adults. American Journal of Orthopsychiatry 85: 565-75. [CrossRef] [PubMed]

Aghababaei, Naser, Agata Błachnio, and Masoume Aminikhoo. 2018. The relations of gratitude to religiosity, well-being and personality. Mental Health, Religion \& Culture 21: 408-17.

Aguinis, Herman, James C. Beaty, Robert J. Boik, and Charles A. Pierce. 2005. Effect size and power in assessing moderating effects of categorical variables using multiple regression: A 30-year review. Journal of Applied Psychology 90: 94-107. [CrossRef] [PubMed]

Aguinis, Herman, Jeffrey R. Edwards, and Kyle J. Bradley. 2017. Improving our understanding of moderation in mediation in strategic management research. Organizational Research Methods 20: 665-85. [CrossRef]

Anderson, Samantha F., Ken Kelley, and Scott E. Maxwell. 2017. Sample-size planning for more accurate statistical power: A method adjusting sample effect sizes for publication bias und uncertainty. Psychological Science 28: 1547-62. [CrossRef] [PubMed]

Ano, Gene G., and Kenneth I. Pargament. 2013. Predictors of spiritual struggles: An exploratory study. Mental Health, Religion \& Culture 16: 419-34.

Ano, Gene G., and Erin B. Vasconcelles. 2005. Religious coping and psychological adjustment to stress: A meta-analysis. Journal of Clinical Psychology 61: 461-80. [CrossRef]

Bertocci, Peter A., and Richard M. Millard. 1963. Personality and the Good: Psychological and Ethical Perspectives. New York: David McKay.

Burke, Laurie A., and Robert A. Neimeyer. 2014. Spiritual distress in bereavement: Evolution of a research program. Religions 5: 1087-115. [CrossRef]

Büssing, Arndt, and Götz Mundle. 2009. Trust in God's help as a measure of intrinsic religiosity and its association with depression and life satisfaction in patients with depressive disorders and addictions. European Journal of Integrative Medicine 1: 190-91. [CrossRef] 
Büssing, Arndt, Andreas Günther, Klaus Baumann, Eckhard Frick, and Christoph Jacobs. 2013. Spiritual dryness as a measure of a specific spiritual crisis in Catholic priests: Associations with symptoms of burnout and distress. Evidence-Based Complementary and Alternative Medicine 2013: 246797. [CrossRef]

Büssing, Arndt, Kazimierz Franczak, and Janusz Surzykiewicz. 2014. Frequency of spiritual/religious practices in Polish patients with chronic diseases: Validation of the Polish version of the SpREUK-P Questionnaire. Religions 5: 459-76. [CrossRef]

Büssing, Arndt, Daniela Rodrigues Recchia, and Klaus Baumann. 2015. Reliance on God's Help Scale as a measure of religious trust-A summary of findings. Religions 6: 1358-67. [CrossRef]

Büssing, Arndt, Eckhard Frick, Christoph Jacobs, and Klaus Baumann. 2016. Spiritual dryness in non-ordained Catholic pastoral workers. Religions 7: 141. [CrossRef]

Büssing, Arndt, Daniela Rodrigues Recchia, Mareike Gerundt, and Markus Warode. 2017. Validation of the SpREUK-Religious Practices Questionnaire as a measure of Christian religious practices in a general population and religious persons. Religions 8: 269. [CrossRef]

Büssing, Arndt, Daniela Rodrigues Recchia, and Klaus Baumann. 2018. Validation of the Gratitude/Awe Questionnaire and its association with disposition of gratefulness. Religions 9: 117. [CrossRef]

Cohen, Jacob. 1988. Statistical Power Analysis for the Behavioral Sciences. New York: Routledge.

Cokley, Kevin O., Samuel Beasley, Andrea Holman, Collette Chapman-Hilliard, Brettjet Cody, Bianca Jones, Shannon McClain, and Desire Taylor. 2013. The moderating role of gender in the relationship between religiosity and mental health in a sample of black American college students. Mental Health, Religion $\mathcal{E}$ Culture 16: 445-62.

Cowchock, F. Susan, Judith N. Lasker, Lori J. Toedter, Stephanie A. Skumanich, and Harold G. Koenig. 2010. Religious beliefs affect grieving after pregnancy loss. Journal of Religion and Health 49: 485-97. [CrossRef]

Currier, Joseph M., Ryon C. McDermott, Darrien E. Hawkins, Chelsea L. Greer, and Rosalie Carpenter. 2018. Seeking help for religious and spiritual struggles: Exploring the role of mental health literacy. Professional Psychology: Research and Practice 49: 90-97. [CrossRef]

Desai, Kavita M., and Kenneth I. Pargament. 2015. Predictors of growth and decline following spiritual struggles. International Journal for the Psychology of Religion 25: 42-56. [CrossRef]

Diener, Ed, Robert A. Emmons, Randy J. Larsen, and Sharon Griffin. 1985. The Satisfaction with Life Scale. Journal of Personality Assessment 49: 71-75. [CrossRef]

Dowson, Martin, and Maureen Miner. 2015. Interacting religious orientations and personal well-being among Australian Church leaders. Mental Health, Religion \& Culture 18: 72-84.

Edmondson, Donald, Crystal L. Park, Stephenie R. Chaudoir, and Jennifer H. Wortman. 2008. Death without God: Religious struggle, death concerns and depression in terminally ill. Psychological Science 19: 754-58. [CrossRef] [PubMed]

Ellison, Christopher G., and Jinwoo Lee. 2010. Spiritual struggle and psychological distress: Is there a dark side of religion? Social Indicators Research 98: 501-17. [CrossRef]

Ellison, Christopher G., Lori A. Roalson, Janelle M. Guillory, Kevin J. Flannelly, and John P. Marcum. 2010. Religious resources, spiritual struggles, and mental health in a nationwide sample of PCUSA Clergy. Pastoral Psychology 59: 287-304. [CrossRef]

Ellison, Christopher G., Qijuan Fang, Kevin J. Flannelly, and Rebecca A. Steckler. 2013. Spiritual struggles and mental health: Exploring the moderating effects of religious identity. International Journal for the Psychology of Religion 23: 214-29. [CrossRef]

Emmons, Robert A. 2013. Gratitude Works: A Twenty-One-Day Program for Creating Emotional Prosperity. San Francisco: Jossey-Bass.

Exline, Julie J., and Eric D. Rose. 2005. Religious and spiritual struggles. In Handbook of Religion and Spirituality. Edited by Raymond F. Paloutzian and Crystal L. Park. New York: Guilford Press, pp. 315-30.

Exline, Julie J., Ann Marie Yail, and William C. Sanderson. 2000. Guilt, discord, and alienation: The role of religious strain in depression and suicidality. Journal of Clinical Psychology 56: 1481-96. [CrossRef]

Exline, Julie J., Joshua B. Grubbs, and Steffany Homolka. 2014a. Seeing God as cruel or distant: Links with divine struggles involving anger, doubt, and fear of God's disapproval. International Journal for the Psychology of Religion 25: 29-41. [CrossRef]

Exline, Julie J., Kenneth I. Pargament, Joshua B. Grubbs, and Ann Marie Yali. 2014b. The Religious and Spiritual Struggle Scale: Development and initial validation. Psychology of Religion and Spirituality 6: 208-22. [CrossRef] 
Fagley, Nancy S. 2012. Appreciation uniquely predict life satisfaction above demographics, the Big 5 personality factors, and gratitude. Personality and Individual Differences 53: 59-63. [CrossRef]

Fairchild, Amanda J., and Heather L. McDaniel. 2017. Best (but oft-forgotten) practices: Mediation analysis. The American Journal of Clinical Nutrition 105: 1259-71. [CrossRef]

Faul, Franz, Edgar Erdfelder, Albert-Georg Lang, and Axel Buchner. 2007. G*Power 3: A flexible statistical power analysis program for the social, behavioral, and biomedical sciences. Behavior Research Methods 39: 175-91. [CrossRef] [PubMed]

Felere, Sergej, and Miran Lavrič. 2008. Is intrinsic religious orientation a culturally specific American Protestant concept? The fusion of intrinsic and extrinsic religious orientation among non-Protestants. European Journal of Social Psychology 38: 521-30. [CrossRef]

Fidell, Linda S., and Barbara G. Tabachnick. 2003. Preparatory data analysis. In Handbook of Psychology: Research Methods in Psychology. Edited by John A. Schinka and Wayne F. Velicer. Hoboken: John Wiley \& Sons, pp. 115-41.

Fisher, Adam R. 2017. A review and conceptual model of the research on doubt, disaffiliation, and related religious changes. Psychology of Religion and Spirituality 9: 358-67. [CrossRef]

Fitchett, George, Bruce Rybarczyk, Gail A. DeMarco, and John J. Nicholas. 1999. The role of religion in medical rehabilitation outcomes: A longitudinal study. Rehabilitation Psychology 44: 333-53. [CrossRef]

Fitchett, George, Patricia E. Murphy, Jo Kim, James L. Gibbons, Jacqueline R. Cameron, and Judy A. Davis. 2004. Religious struggle: Prevalence, correlates and mental failure, and onclology patients. International Journal of Psychiatry in Medicine 34: 179-96. [CrossRef] [PubMed]

Fredrickson, Barbara L. 2001. The role of positive emotions in positive psychology: The broaden-and-build theory of positive emotions. American Psychologist 56: 218-26. [CrossRef] [PubMed]

Fredrickson, Barbara L., Michele M. Tugade, Christian E. Waugh, and Gregory R. Larkin. 2003. What good are positive emotions in crises? A prospective study of resilience and emotions following the terrorist attacks on the United States on September 11th, 2001. Journal of Personality and Social Psychology 84: 365-67. [CrossRef]

Froh, Jeffrey J., Charles Yurkiewicz, and Todd Kashadan. 2009a. Gratitude and subjective well-being in early adolescences: Examining gender differences. Journal of Adolescence 32: 633-50. [CrossRef]

Froh, Jeffrey J., Todd B. Kashdan, Kathleen M. Ozimkowski, and Norman Miller. 2009b. Who benefits the most from a gratitude intervention in children and adolescents? Examining positive affect as a moderator. Journal of Positive Psychology 4: 408-22. [CrossRef]

Galek, Kathleen, Neal Krause, Christopher G. Ellison, Taryn Kudler, and Kevin J. Flannelly. 2007. Religious doubt and mental health across the lifespan. Journal of Adult Development 14: 16-25. [CrossRef]

García-Alandete, Joaquín, and Gloria Bernabé Valero. 2013. Religious orientation and psychological well-being among Spanish undergraduates. Accíon Psicológica 10: 133-48.

George, Darren, and Paul Mallery. 2016. IBM SPSS Statistics 23 Step by Step: A Simple Guide and Reference. New York: Routledge.

George, Linda K., Christopher G. Ellison, and David B. Larson. 2002. Explaining the relationships between religious involvement and health. Psychological Inquiry 13: 190-200. [CrossRef]

Gutierrez, Ian A., Crystal L. Park, and Bradley R. E. Wright. 2017. When the divine defaults: Religious struggle mediates the impact of financial stressors on psychological distress. Psychology of Religion and Spirituality 9: 387-98. [CrossRef]

Hair, Joseph F., G. Tomas M. Hult, Christian M. Ringle, and Marko Sarstedt. 2017. A Primer on Partial Less Squares Structural Equation Modeling (PLS-SEM). Los Angeles: SAGE Publications.

Hayes, Andrew F. 2013. Introduction to Mediation, Moderation, and Conditional Process Analysis: A Regression-Based Approach. New York: Guilford.

Heelas, Paul. 1985. Social anthropology and the psychology of religion. In International Series in Experimental Social Psychology. Vol. 11. Advances and the Psychology of Religion. Edited by Laurence B. Brown. New York: Pergamon Press, pp. 34-51.

Hill, Peter C. 2005. Measurement in psychology of religion and spirituality: Current status and evaluation. In Handbook of Religion and Spirituality. Edited by Raymond F. Paloutzian and Crystal L. Park. New York: Guilford Press, pp. 43-61. 
Hill, Peter C., and Kenneth I. Pargament. 2008. Advances in the conceptualization and measurement of religion and spirituality: Implications for physical and mental health. Psychology of Religion and Spirituality 5: 3-17. [CrossRef]

Holcomb, Gay L., and Arthur J. Nonneman. 2004. Faithful change: Exploring and assessing faith development in Christian liberal arts undergraduates. New Directions for Institutional Research 122: 93-103. [CrossRef]

Johnson, Thomas J., Virgil L. Sheets, and Jean L. Kristeller. 2008. Empirical identification of dimensions of religiousness and spirituality. Mental Health, Religion \& Culture 11: 745-67.

Juczyński, Zygfryd. 2001. Narzędzia pomiaru w promocji psychologii zdrowia. Warszawa: Pracownia Testów Psychologicznych.

King, Stephen Duane, George Fitchett, Patricia E. Murphy, Kenneth I. Pargament, Paul J. Martin, Rebecca H. Johnson, David A. Harrison, and Elizabeth Trice Loggers. 2017. Spiritual or religious struggle in hematopoietic cell transplant survivors. Psycho-Oncology 26: 270-77. [CrossRef]

Kleiman, Evan M., Leah M. Adams, Todd B. Kashdan, and John H. Riskind. 2013. Grateful individuals are not suicidal: Buffering risks associated with hopelessness and depressive symptoms. Personality and Individual Differences 55: 595-99. [CrossRef]

Kline, Rex B. 2015. The mediation myth. Basic and Applied Social Psychology 37: 202-13. [CrossRef]

Koenig, Harold G. 2012. Religion, spirituality, and health: The research and clinical implications. ISRN Psychiatry 2012: 1-33. [CrossRef]

Koenig, Harold G., Michael E. McCullough, and David B. Larson. 2001. Handbook of Religion and Health: A Century of Research Reviewed. New York: Oxford University Press.

Kossakowska, Marlena, and Piotr Kwiatek. 2014. Polska adaptacja kwestionariusza do badania wdzięczności GQ-6. Przegląd Psychologiczny 57: 503-14.

Krause, Neal. 2015. Religious doubt, helping others, and psychological well-being. Journal of Religion and Health 54: 745-58. [CrossRef] [PubMed]

Krause, Neal, and Christopher G. Ellison. 2003. Forgiveness by God, forgiveness of others, and psychological well-being in late life. Journal of Scientific Study of Religion 42: 77-94. [CrossRef]

Krause, Neal, and Richard David Hayward. 2013. Prayer beliefs and change in life satisfaction over time. Journal of Religion and Health 52: 674-94. [CrossRef] [PubMed]

Krause, Neal, Berit Ingersoll-Dayton, Christopher G. Ellison, and Keith M. Wulff. 1999. Aging, religious doubt, and psychological well-being. The Gerontologist 39: 525-33. [CrossRef] [PubMed]

Krok, Dariusz. 2014. The religious meaning system and subjective well-being: The meditational perspective of meaning in life. Archive for The Psychology of Religion 36: 253-73. [CrossRef]

Kwako Golo, Ben-Willie, Måns Broo, Sławomir Sztajer, Francis Benyah, Sohini Ray, and Mallarika Sarkar. 2019. Primary religious socialization agents and young adults' understanding of religion: Connections and disconnections. Religion 49: 179-200. [CrossRef]

Lakens, Daniel. 2013. Calculating and reporting effect sizes to facilitate cumulative science: A practical primer for $t$-tests and ANOVAs. Frontiers in Psychology 4: 863. [CrossRef]

Lambert, Nathaniel M., Frank D. Fincham, Tyler F. Stillman, and Lukas R. Dean. 2009. More gratitude, less materialism: The mediating role of life satisfaction. Journal of Positive Psychology 4: 32-42. [CrossRef]

Lim, Chaeyoon, and Robert D. Putnam. 2010. Religion, social networks, and life satisfaction. American Sociological Review 75: 914-33. [CrossRef]

Lomax, Richard G., and Debbie L. Hahs-Vaughn. 2012. Statistical Concepts: A Second Course. New York: Routledge.

Magyar-Russell, Gina, Iain Tucker Brown, Inna R. Edara, Michael T. Smith, Joseph E. Marine, and Roy C. Ziegelstein. 2014. In search of serenity: Religious struggle among patients hospitalized for suspect acute coronary syndrome. Journal of Religion and Health 53: 562-78. [CrossRef] [PubMed]

Martell, Richard, David Mark Lane, and Cynthia Emrich. 1996. Male-female differences: A computer simulation. American Psychologist 51: 157-58. [CrossRef]

Maxwell, Scott E., and David A. Cole. 2007. Bias in cross-sectional analyses of longitudinal meditation. Psychological Methods 12: 23-44. [CrossRef] [PubMed]

McConnell, Kelly M., Kenneth I. Pargament, Christopher G. Ellison, and Kevin J. Flannelly. 2006. Examining the links between spiritual struggles and symptoms of psychopathology in a national sample. Journal of Clinical Psychology 62: 1469-84. [CrossRef] [PubMed] 
McCullough, Michael E., Robert A. Emmons, and Jo-Ann Tsang. 2002. The grateful disposition: A conceptual and empirical topography. Journal of Personality and Social Psychology 82: 112-27. [CrossRef] [PubMed]

Mehmetoglu, Mehmet, and Tor Georg Jakobsen. 2017. Applied Statistics Using Stata: A Guide for the Social Sciences. London: SAGE Publications.

Morgan, George Arthur, and Orlando V. Griego. 1998. Easy Use and Interpretation of SPSS for Windows: Answering Research Questions with Statistics. Mahwah: Lawrence Erlbaum Associates.

Murphy, Patricia E., George Fitchett, and Erin E. Emery-Tiburcio. 2016. Religious and spiritual struggle: Prevalence and correlates among older adults with depression in the BRIGHTEN Program. Mental Health, Religion $\mathcal{E}$ Culture 19: 713-21.

Neimeyer, Robert A., and Laurie A. Burke. 2011. Complicated grief in the aftermath of homicide: Spiritual crisis and distress in an African American sample. Religions 2: 145-64. [CrossRef]

Pargament, Kenneth I., Harold G. Koenig, Nalini Tarakeshwar, and June Hahn. 2001. Religious struggle as a predictor of morality among medically ill elderly patients: A 2-year longitudinal study. Archives of Internal Medicine 161: 1881-85. [CrossRef]

Pargament, Kenneth I., Nichole A. Murray-Swank, Gina M. Magyar, and Gene G. Ano. 2005. Spiritual struggle: A phenomenon of interest to psychology and religion. In Judeo-Christian Perspectives on Psychology: Human Nature, Motivation and Change. Edited by William R. Miller and Harold D. Delaney. Washington: American Psychological Association, pp. 245-68.

Park, Crystal L., Donald Edmondson, Amy Hale-Smith, and Thomas O. Blank. 2009. Religiousness/spirituality and health behaviors in younger adult cancer survivors: Does faith promote a healthier life style? Journal of Behavioral Medicine 32: 582-91. [CrossRef]

Park, Crystal L., Jennifer H. Wortmann, and Donald Edmondson. 2011. Religious struggle as a predictor of subsequent mental and physical well-being in advanced failure patients. Journal of Behavioral Medicine 34: 426-36. [CrossRef]

Pavot, William, and Ed Diener. 1993. Review of the Satisfaction with Life Scale. Psychological Assessment 5: 164-72. [CrossRef]

Poelker, Katelyn E., Judith L. Gibbons, Colleen A. Maxwell, and Ingrid Lorena Elizondo-Quintanilla. 2017. Envy, gratitude, and well-being among Guatemalan adolescents with scarce economic resources. International Perspectives in Psychology: Research, Practice, Consultation 6: 209-26. [CrossRef]

PRC (Pew Research Center). 2018. Available online: https://www.pewforum.org/2018/06/13/young-adults-aroundthe-world-are-less-religious-by-several-measures/ (accessed on 25 April 2019).

Preacher, Kristopher J., and Andrew F. Hayes. 2008. Asymptotic and resampling strategies for assessing and comparing indirect effects in multiple mediator models. Behavior Research Methods 40: 879-91. [CrossRef] [PubMed]

Proffitt, Deborah, Arnie Cann, Lawrence G. Calhoun, and Richard G. Tedeschi. 2007. Judeo-Christian clergy and personal crisis: Religion, posttraumatic growth and well-being. Journal of Religion and Health 46: 219-31. [CrossRef]

Sansone, Randy A., and Lori A. Sansone. 2010. Gratitude and well-being: The benefits of appreciation. Psychiatry 7: 18-22. [PubMed]

Sedlar, Aaron E., Nick Stauner, Kenneth I. Pargament, Julie J. Exline, Joshua B. Grubbs, and David F. Bradley. 2018. Spiritual struggles among atheists: Links to psychological distress and well-being. Religions 9: 242. [CrossRef]

Sherman, Allen C., Stephanie Simonton, Umaira Latif, Rebecca Spohn, and Guido Tricot. 2005. Religious struggle and religious comfort in response to illness: Health outcomes among stem cell transplant patients. Journal of Behavioral Medicine 28: 359-67. [CrossRef]

Silberman, Israela. 2005. Religion as a meaning system: Implications for the new millennium. Journal of Social Issues 61: 641-63. [CrossRef]

Smith, Timothy B., Michael E. McCullough, and Justin Poll. 2003. Religiousness and depression: Evidence for a main effect and the moderating influence of stressful life event. Psychological Bulletin 129: 614-39. [CrossRef]

Stevens, James P. 2009. Applied Multivariate Statistics for the Social Sciences. New York: Routledge.

ten Kate, Josje, Willem de Koster, and Jeroen van der Waal. 2017. The effect of religiosity on life satisfaction in a secularized context: Assessing the relevance of believing and belonging. Review of Religious Research 59: 135-55. [CrossRef] 
Thompson, Christopher Glen, Rae Seon Kim, Ariel M. Aloe, and Betsy Jane Becker. 2017. Extracting the variance inflation factor and other multicollinearity diagnostics from typical regression results. Basic and Applied Psychology 39: 81-90. [CrossRef]

Tobin, Erin T., and Richard B. Slatcher. 2016. Religious participation predicts diurnal cortisol profiles 10 years later via lower levels of religious struggle. Health and Psychology 35: 1356-63. [CrossRef] [PubMed]

Watkins, Philip C. 2004. Gratitude and subjective well-being. In The Psychology of Gratitude. Edited by Robert A. Emmons and Michael E. McCullough. Series in Affective Science; New York: Oxford University Press, pp. 167-92.

Watkins, Philip C., Kathrane Woodwart, Tamara Stone, and Russell L. Kolts. 2003. Gratitude and happiness: Development of a measure of gratitude, and relationships with subjective well-being. Social Behavior and Personality 31: 431-52. [CrossRef]

Wilt, Joshua A., Joshua B. Grubbs, Julie J. Exline, and Kenneth I. Pargament. 2016. Personality, religious and spiritual struggles and well-being. Psychology of Religion and Spirituality 8: 341-51. [CrossRef]

Wong, Y. Joel, Nancy McKean Blackwell, Nicole T. Gabana, Nancy Goodrich Mitts, and Yue Li. 2017. Giving thanks together: A preliminary evaluation of the Gratitude Group Program. Practice Innovations 2: $243-57$. [CrossRef]

Wood, Alex M., John Maltby, Raphael Gillet, P. Alex Linley, and Stephen Joseph. 2008a. The role of gratitude in the development of social support, stress and depression: Two longitudinal studies. Journal of Research in Personality 42: 854-71. [CrossRef]

Wood, Alex M., John Maltby, Stewart Neil, and Joseph Stephen. 2008b. Conceptualizing gratitude and appreciation as a unitary personality trait. Personality and Individual Differences 44: 619-30. [CrossRef]

Yeniaras, Volkan, and Tugra Nazil Akarsu. 2017. Religiosity and life satisfaction: A Multi-dimensional approach. Journal of Happiness Studies 18: 1815-40. [CrossRef]

Zahl, Bonnie Poon, and Nicholas J. S. Gibson. 2012. God representations, attachment to God, and satisfaction with life: A comparison of doctrinal and experiential representations of God in Christian young adults. International Journal for the Psychology of Religion 22: 216-30. [CrossRef]

Zarzycka, Beata. 2014. The internal structure of the Polish adaptation of The Religious Comfort and Strain Scale. Annals of Psychology 17: 697-710.

Zarzycka, Beata, and Małgorzata M. Puchalska-Wasyl. 2019. Can religious and spiritual struggle enhance well-being? Exploring the mediating effects of internal dialogues. Journal of Religion and Health. [CrossRef]

Zarzycka, Beata, and Pawel Zietek. 2018. Spiritual growth or decline and meaning-making as mediators of anxiety and satisfaction with life during religious struggle. Journal of Religion and Health. [CrossRef]

Zarzycka, Beata, Dominika Ziółkowska, and Jacek Śliwak. 2017. Religious support and religious struggle as predictors of quality of life in Alcoholics Anonymous-Moderation by duration of abstinence. Roczniki Psychologiczne 20: 121-42. [CrossRef]

(C) 2019 by the authors. Licensee MDPI, Basel, Switzerland. This article is an open access article distributed under the terms and conditions of the Creative Commons Attribution (CC BY) license (http://creativecommons.org/licenses/by/4.0/). 